\title{
Estrogen deprivation in primate pregnancy leads to insulin resistance in offspring
}

\author{
Adina Maniu', Graham W Aberdeen', Terrie J Lynch², Jerry L Nadler³, Soon O K Kim², \\ Michael J Quon4, Gerald J Pepe², and Eugene D Albrecht1 \\ 1Department of Obstetrics, Gynecology, and Reproductive Sciences, University of Maryland School of \\ Medicine, Baltimore, Maryland, USA \\ 2Department of Physiological Sciences, Eastern Virginia Medical School, Norfolk, Virginia, USA \\ 3Department of Internal Medicine, Eastern Virginia Medical School, Norfolk, Virginia, USA \\ ${ }^{4}$ Department of Medicine, University of Maryland School of Medicine, Baltimore, Maryland, USA
}

Correspondence should be addressed to E D Albrecht

Email

ealbrecht@fpi.umaryland.edu

\begin{abstract}
This study tested the hypothesis that estrogen programs mechanisms within the primate fetus that promote insulin sensitivity and glucose homeostasis in offspring. Glucose tolerance tests were performed longitudinally in prepubertal offspring of baboons untreated or treated on days 100 to $165 / 175$ of gestation (term is 184 days) with the aromatase inhibitor letrozole, which decreased fetal estradiol levels by $95 \%$. Basal plasma insulin levels were over two-fold greater in offspring delivered to letrozole-treated than untreated animals. Moreover, the peak $1 \mathrm{~min}$, average of the 1, 3, and $5 \mathrm{~min}$, and area under the curve blood glucose and plasma insulin levels after an i.v. bolus of glucose were greater $(P<0.05$ and $P<0.01$, respectively) in offspring deprived of estrogen in utero than in untreated animals and partially or completely restored in letrozole plus estradiol-treated baboons. The value for the homeostasis model assessment of insulin resistance was 2.5 -fold greater $(P<0.02)$ and quantitative insulin sensitivity check index lower $(P<0.01)$ in offspring of letrozole-treated versus untreated animals and returned to almost normal in letrozole plus estradiol-treated animals. The exaggerated rise in glucose and insulin levels after glucose challenge in baboon offspring deprived of estrogen in utero indicates that pancreatic beta cells had the capacity to secrete insulin, but that peripheral glucose uptake and/or metabolism were impaired, indicative of insulin resistance and glucose intolerance. We propose that estrogen normally programs mechanisms in utero within the developing primate fetus that lead to insulin sensitivity, normal glucose tolerance, and the capacity to metabolize glucose after birth.
\end{abstract}

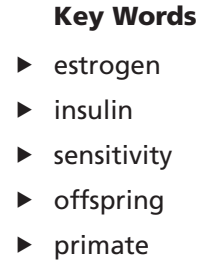

Journal of Endocrinology (2016) 230, 171-183

\section{Introduction}

Estrogen has a fundamentally important role in the adult in regulating pancreatic islet beta-cell integrity and function and consequently the secretion and action of insulin important for the control of metabolism of glucose (reviewed in Liu \& Mauvais-Jarvis 2010, MauvaisJarvis et al. 2013, Gupte et al. 2015). Thus, estrogen stimulates proliferation (Choi et al. 2005) and protects against apoptosis (LeMay et al. 2006) of beta-cells in 
adult rodents and improves glucose-stimulated insulin secretion (Godsland 2005) and decreases the incidence of diabetes (Margolis et al. 2004) in postmenopausal women. Indeed, a sex-specific effect exists in which the incidence of diabetes mellitus is lower in women than in men, a benefit that is lost after menopause (Gale \& Gillespie 2001, Louet et al. 2004, Moran et al. 2008, Geer \& Shen 2009). Moreover, in several animal models, estradiol at physiological levels inhibits, and androgens stimulate, oxidative stress-induced pancreatic beta-cell glucolipotoxicity and apoptosis (Paik et al. 1982, Le May et al. 2006, Nadal et al. 2009).

In addition to its effects on pancreatic beta-cell integrity and insulin secretion, estrogen also promotes insulin action. Thus, mice lacking estrogen receptor $\alpha$ (ER $\alpha$ (ESR1)) exhibit insulin resistance within skeletal muscle and liver (Bryzgalova et al. 2006, Ribas et al. 2011, Manrique et al. 2012). In humans and rodents, mutation of the aromatase gene results in insulin insensitivity and glucose intolerance (Jones et al. 2000, Rochira et al. 2000, Takeda et al. 2003, Belgorosky et al. 2009). ER $\alpha$ is highly expressed in insulin-sensitive target tissues, including skeletal muscle (Deroo \& Korach 2006, Heldring et al. 2007, Wiik et al. 2009). Estradiol stimulates insulin sensitivity and enhances glucose tolerance in skeletal muscle of adult mice (Gao et al. 2006, Lundholm et al. 2008, Riant et al. 2009) and protects ovariectomized mice from high-fat-diet-induced insulin resistance (Camporez et al. 2013, Jelenik \& Roden 2013). Administration of the ER $\alpha$ agonist propylpyrazoletriyl and estradiol activation of Akt (Vasconsuelo et al. 2008, Rogers et al. 2009), an essential step in insulin receptor signaling, increases GLUT4 receptor protein transcription and glucose uptake in skeletal muscle of adult rats (Barros et al. 2006, 2009, Gorres et al. 2011). Estrogen replacement therapy reverses the increased incidence of insulin resistance, which occurs in postmenopausal women (Karjalainen et al. 2001, Margolis et al. 2004, Manson et al. 2013). Estrogen also restores insulin sensitivity and glucose metabolism in ovariectomized rhesus monkeys fed a high-fat diet (Wagner et al. 1998).

Although the vast majority of studies of the effects of estrogen on insulin secretion and insulin action have been conducted in the adult, very little is known about the role of the hormonal milieu in utero and the mechanisms integral to fetal development that prepare the offspring for controlling insulin secretion and action and glucose homeostasis after birth. We have shown that the baboon provides a superb nonhuman primate translational model for the study of placental, developmental, and perinatal biology (Albrecht \& Pepe 1990, Pepe \& Albrecht 1995). In the present study, therefore, we used the baboon, and a highly specific aromatase inhibitor, letrozole, was used to suppress placental estrogen production and levels within the fetus during the second half of gestation to test the hypothesis that within the developing fetus estrogen programs mechanisms that promote insulin secretion and action and glucose homeostasis in offspring after birth. Moreover, basal fasting levels of the insulin receptor signaling components within skeletal muscle, where over $80 \%$ of total insulin-directed glucose uptake and metabolism occur (DeFronzo et al. 1981), were also quantified in the baboon fetus near term to determine the activity of the insulin receptor signaling pathway before delivery of the offspring and postnatal life.

\section{Materials and methods}

\section{Animals}

Pregnant baboons Female baboons (Papio anubis), originally obtained from the Southwest National Primate Research Center, San Antonio, TX, USA were housed individually in large primate cages in air-conditioned rooms with a $12 \mathrm{~h}$ light: $12 \mathrm{~h}$ darkness lighting cycle and fed standard primate chow (Harlan Primate Diet, Madison, WI, USA) twice daily, fresh fruit and vitamins daily, and water ad libitum. Female baboons were paired with male baboons for 5 days at mid-cycle and pregnancy was confirmed by ultrasound. Pregnant baboons were then either untreated or treated between days 100 and $165-175$ of gestation (term $=184$ days) with the aromatase inhibitor letrozole (4,4-[1,2,3-triazol-1-yl-methylene]bisbenzonitrate, Novartis Pharma AG, Basel, Switzerland; $115 \mu \mathrm{g} / \mathrm{kg}$ body weight/day, via maternal s.c. injection in $1.0 \mathrm{~mL}$ sesame oil) or with letrozole $(115 \mu \mathrm{g} / \mathrm{kg}$ body weight/day) plus estradiol benzoate (beginning at $25 \mu \mathrm{g} / \mathrm{kg}$ on day 100 and increasing to maximum of $115 \mu \mathrm{g} / \mathrm{kg}$ body weight between days 120 and 165-175). Blood samples (2-3 mL) were obtained at 1-3 day intervals during the second half of gestation from a peripheral maternal saphenous vein after brief restraint and sedation with ketamine $\mathrm{HCl}(10 \mathrm{mg} / \mathrm{kg}$ body weight, i.m.) and serum estradiol levels quantified by immulite RIA (Albrecht $e t$ al. 2000). The use of baboons for this study was approved by the Institutional Animal Care and Use Committees of the University of Maryland School of Medicine and Eastern Virginia Medical School.
(C) 2016 Society for Endocrinology Printed in Great Britain
Published by Bioscientifica Ltd. 
Fetal development On day 165 of gestation, 5 of the fetuses ( 1 female, 4 males) from untreated baboons and 5 of the fetuses ( 1 female, 4 males) from letrozoletreated animals were delivered via cesarean section during isoflurane anesthesia, $2 \mathrm{~mL}$ blood sample was obtained from the umbilical artery for glucose and insulin assay, and fetuses were immediately killed by an i.v. injection of pentobarbital $(100 \mathrm{mg} / \mathrm{kg}$ body weight). A section $(10 \times 10 \mathrm{~mm})$ of vastus lateralis skeletal muscle was then excised, frozen on dry ice, and stored at $-80^{\circ} \mathrm{C}$ until assayed for insulin signaling molecules.

Postnatal development On days 165-175 of gestation, the remaining offspring from baboon mothers that had been untreated or treated with letrozole \pm estradiol were either delivered spontaneously or were anesthetized with isoflurane and after obtaining an umbilical artery blood sample $(2 \mathrm{~mL})$ delivered by cesarean section to synchronize the timing of delivery. Baboon newborns that had been untreated ( 7 females, 3 males) or treated in utero with letrozole (3 females, 2 males) or letrozole plus estradiol ( 2 females, 2 males) were then left with and nursed by their mothers for 8 months at which time they were weaned and placed in pairs in cages immediately adjacent to their respective mothers and fed standard primate chow (Harlan Primate Diet, Madison, WI, USA) twice daily, fresh fruit and vitamins daily, and water ad libitum. Every 2-6 months thereafter, baboon offspring were briefly sedated with ketamine $\mathrm{HCl}(10 \mathrm{mg} / \mathrm{kg}$ body weight, i.m.), and body weight and blood pressure (Dinamap Pro 400, GE Medical Systems, Milwaukee, WI, USA) were measured with animals in the supine position. At this time, a blood sample $(2-3 \mathrm{~mL})$ was also withdrawn from a peripheral saphenous vein for the purpose of quantifying serum estradiol and testosterone levels by immulite RIA.

\section{Glucose tolerance test}

To avoid the potential impact on insulin action/glucose metabolism of the rise in estrogen and testosterone levels associated with the onset of puberty, an i.v. glucose tolerance test was performed, according to the established method of Overkamp and coworkers (Overkamp et al. 1997), sequentially, i.e. 3-5 times, on each baboon offspring at 6-12 month intervals between the postnatal ages of 1 and $3 \frac{1}{4}$ years of age, i.e. before puberty which occurs at $3 \frac{1}{2}$ years in females and $4 \frac{1}{2}$ years of age in males within our baboon colony. The data obtained from the several glucose tolerance tests performed were averaged to yield a single value for each animal. Baboons were fasted overnight and at 08:00 $\mathrm{h}$ the following morning sedated with ketamine $\mathrm{HCl}$ (initially $5-10 \mathrm{mg} / \mathrm{kg}$ body weight, i.m.; then $2 \mathrm{mg} / \mathrm{kg}$ body weight, i.v.) and positioned on their left side on a $37^{\circ} \mathrm{C}$ heating pad. Using a 21 -gauge needle, a bolus injection of $0.25 \mathrm{~g} / \mathrm{kg}$ body weight of dextrose was administered into an antecubital vein at time $0 \mathrm{~h}$. Blood samples ( $2.5 \mathrm{~mL}$ each) were obtained via a sterile catheter (21 gauge) inserted into a peripheral saphenous vein at -2 (i.e. basal fasting), 1, 3, 5, 10, 20, 40,60 , and $90 \mathrm{~min}$ before/after dextrose administration.

To determine the potential impact of estrogen deprivation on glucose metabolism in maternal baboons before delivery, an i.v. glucose test was also performed as described above between days 151 and 163 of gestation in ketamine-sedated untreated $(n=4)$, letrozole-treated $(n=6)$, and letrozole plus estradiol-treated $(n=4)$ baboon mothers.

\section{Glucose and insulin assay}

Blood glucose levels were determined via an iStat Portable Clinical Analyzer (Model \#210003, Abbott Laboratories) on $0.1 \mathrm{~mL}$ blood. The remainder of the blood sample was collected into a heparinized tube on ice, centrifuged at $3500 \mathrm{~g}$ for $15 \mathrm{~min}$ and the plasma stored at $-20^{\circ} \mathrm{C}$ for determination of insulin level by solid-phase chemiluminescent immunometric assay via an Immulite System (Siemens Healthcare). The insulin assay employed a monoclonal murine anti-insulin antibody and internal insulin standard curve displayed a sensitivity of $2 \mu \mathrm{IU} / \mathrm{mL}$ and intra- and interassay coefficients of variation of 5.7 and $5.9 \%$, respectively, and exhibited no cross-reactivity with other peptides.

\section{Western immunoblot}

Samples of fetal skeletal muscle were homogenized and lysed on ice-cold PBS containing 1\% cholic acid, $0.1 \%$ SDS, $1 \mathrm{mM}$ EDTA (Sigma-Aldrich), and a protease inhibitor cocktail, essentially as described previously (Zachos et al. 2004). Briefly, after determination of protein concentration using the bicinchoninic acid method (Sigma-Aldrich), the samples (50 $\mu$ g protein) were mixed with $5 \mathrm{X}$ Laemmli buffer, heated to $95^{\circ} \mathrm{C}$ for $5 \mathrm{~min}$, cooled on ice for $2 \mathrm{~min}$, and centrifuged $(800 \mathrm{~g})$. They were then loaded onto $7.5 \%$ (IRS-1, AS160) or $10 \%$ (Akt/pAkt, GLUT1, GLUT4/pGLUT4) SDS-polyacrylamide gels (PAGE) and electrophoresed using a Bio-Rad

Published by Bioscientifica Ltd 
Mini-Protean electrophoresis chamber (Bio-Rad Laboratories) and SDS-PAGE running buffer comprising $25 \mathrm{mM}$ Tris ( $\mathrm{pH} 8.3$ ), $192 \mathrm{mM}$ glycine, and $0.1 \%$ SDS. Proteins were wet-transferred onto an Immobilon-P membrane (Millipore); blocked $1 \mathrm{~h}$ at room temperature with 5\% BSA in $10 \mathrm{mM}$ Tris-HCl, pH 7.5, $150 \mathrm{mM} \mathrm{NaCl}$, and $0.2 \%$ Tween-20 buffer (TBST); and then incubated overnight at $4^{\circ} \mathrm{C}$ with the following primary rabbit polyclonal antibodies diluted in TBST containing 5\% BSA: anti-Akt (1:500 dilution, Cell Signaling), anti-pAkt-S473 (1:500, Cell Signaling), anti-pAkt-T308 (1:500, Abcam), anti-AS160 (1:1,000, Cell Signaling), anti-GLUT1 (1:500, Abcam), anti-pGLUT4-S488 (1:1,000, Abcam), anti-IRS-1 (1:5,000, Thermo Fisher), and anti-GAPDH (1:5,000, Abcam), and mouse monoclonal anti-GLUT4 (1:1,000, Abcam). After three washes (6 min) in TBST, the membranes were incubated for $1 \mathrm{~h}$ at room temperature with horseradish peroxidase (HRP)-labeled secondary antibody (Serotec UK) in TBST containing 5\% BSA. After washing in TBST, the membranes were developed with enhanced chemiluminescence (GE Healthcare) according to manufacturer's instructions and exposed to Fuji Super RX medical X-ray film (Fujifilm Medical Systems, Inc, Roselle, IL, USA), and band intensities quantified by densitometry using Image J software (National Institutes of Health). The blots were then stripped and reprobed using HRP-conjugated GAPDH as an internal loading control and

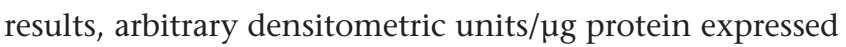
as a ratio to GAPDH. Specificity of the primary antibodies was determined by incubation of samples without primary antibody.

\section{Statistical analysis}

Baboons were randomly assigned to the treatment groups and data were expressed as mean \pm s.E.M. Data were analyzed by ANOVA with post hoc comparison of the means by either Tukey-Kramer multiple comparisons test or Kruskal-Wallis nonparametric test using SAS statistical software (SAS Institute, Cary, NC, USA).

\section{Results}

\section{Serum steroid hormone levels}

Maternal peripheral saphenous vein serum estradiol levels in untreated baboons increased from a mean \pm s.E.M. of $1.0 \pm 0.2 \mathrm{ng} / \mathrm{mL}$ on day 100 (i.e. midgestation) to $3.6 \pm 0.4 \mathrm{ng} / \mathrm{mL}$ on days $165 / 175$ of gestation. The administration of letrozole beginning on day 100 resulted in serum estradiol concentrations which rapidly declined within 2 days to and remained at levels of $<0.1 \mathrm{ng} / \mathrm{mL}$. Concomitant administration of letrozole and estradiol resulted in a pattern of increasing maternal peripheral serum estradiol levels that was similar to that in untreated animals. Consequently, at the time of delivery on days $165-175$ of gestation, serum estradiol concentrations in blood delivered from the fetus (i.e. umbilical artery) of letrozole-treated baboons $(46 \pm 5 \mathrm{pg} / \mathrm{mL})$ was only $5 \%$ of that $(P<0.001)$ in untreated animals $(590 \pm 72 \mathrm{pg} / \mathrm{mL}$, Fig. 1). Umbilical artery serum estradiol levels in letrozole plus estradiol-treated baboons were increased to a level $(133 \pm 19 \mathrm{pg} / \mathrm{mL})$ almost three-fold greater $(P<0.01)$ than that in animals treated with letrozole alone, but remained lower $(P<0.001)$ than in untreated animals.

Umbilical artery serum testosterone levels on days $165-175$ in letrozole-treated baboons $(3.7 \pm 0.3 \mathrm{ng} / \mathrm{mL})$ were over three-fold greater $(P<0.01)$ than that in untreated controls $(1.1 \pm 0.2 \mathrm{ng} / \mathrm{mL}$, Fig. 1). Serum testosterone levels remained elevated in baboons treated with both letrozole and estradiol, because of continued inhibition of aromatization of $\mathrm{C}_{19}$ steroid precursors to estrogen in these animals.

\section{Postnatal development}

Growth and serum analytes Body weights on days $165-175$ of gestation were similar in newborns delivered to untreated, letrozole-treated, and letrozole plus estradioltreated baboons (Table 1). However, placental weight was

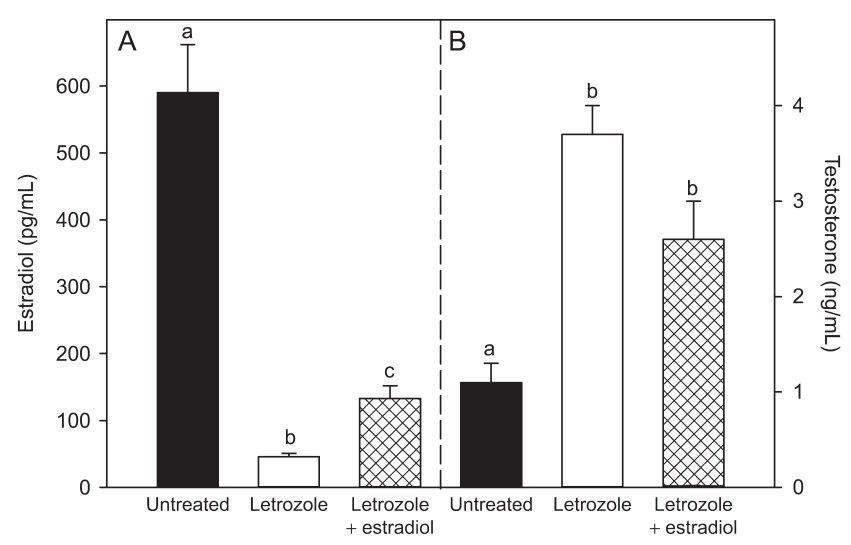

Figure 1

Umbilical artery serum estradiol (A) and testosterone (B) levels (mean \pm S.E.M.) on days 165-175 of gestation in baboons untreated or treated on days $100-165 / 175$ with letrozole $(115 \mu \mathrm{g} / \mathrm{kg}$ body weight/day via maternal s.c. injection) or letrozole $(115 \mu \mathrm{g} / \mathrm{kg}$ body weight) plus estradiol (25-115 $\mu \mathrm{g} / \mathrm{kg}$ body weight/day). Data bars marked with different letters are significantly different $(P<0.01$, ANOVA,

Tukey-Kramer multiple comparison statistic) from one another. 
Table 1 Placental weight and newborn body weight and fasting blood glucose and plasma insulin levels in baboons.

\begin{tabular}{|c|c|c|c|c|}
\hline Treatment & $\begin{array}{c}\text { Placental wt } \\
\text { (gm) }\end{array}$ & $\begin{array}{c}\text { Body wt } \\
\text { (gm) }\end{array}$ & $\begin{array}{c}\text { Glucose } \\
\text { (mg/dL) }\end{array}$ & $\begin{array}{c}\text { Insulin } \\
(\mu \mathrm{IU} / \mathrm{mL})\end{array}$ \\
\hline Untreated & $183 \pm 9$ & $\overline{810 \pm 27}$ & $74 \pm 6$ & $3.7 \pm 0.3$ \\
\hline Letrozole & $207 \pm 16 *$ & $790 \pm 62$ & $70 \pm 8$ & $4.1 \pm 0.4$ \\
\hline Letrozole + estradiol & $176 \pm 12$ & $767 \pm 59$ & $75 \pm 7$ & $3.9 \pm 0.7$ \\
\hline
\end{tabular}

Values are expressed as mean \pm S.E.M. on the day of delivery (days 165-175 of gestation) in newborns from baboons untreated $(n=10)$ or treated on days $100-165 / 175$ of gestation (term $=184$ days) with letrozole $(115 \mu \mathrm{g} / \mathrm{kg}$ body weight/day via maternal s.c. injection, $n=5)$ or letrozole $(115 \mu \mathrm{g} / \mathrm{kg}$ body weight) plus estradiol (25-115 $\mu \mathrm{g} / \mathrm{kg}$ body weight/day, $n=4)$.

$* P<0.05$ vs untreated.

approximately $10 \%$ greater $(P<0.05)$ in letrozole-treated than that in untreated animals and returned to normal by letrozole plus estrogen treatment (Table 1).

The body weights of baboon offspring increased $(P<0.01)$ progressively throughout postnatal life, reaching levels at 3 years of age that were similar in animals untreated and treated in utero with letrozole or letrozole plus estrogen (Table 2). Corresponding with the normal rate of growth, mean arterial blood pressure and levels of serum chemistry analytes, including AST, creatinine, triglycerides, and cholesterol, were similar at birth, throughout postnatal maturation, and at 3 years of age in offspring delivered to baboons untreated or treated during the second half of gestation with letrozole or letrozole plus estradiol (Table 2).

Serum estradiol levels in female baboon offspring that had been untreated or treated in utero with letrozole or letrozole plus estradiol were very low (i.e. $15-30 \mathrm{pg} / \mathrm{mL}$ ) throughout the first $3 \frac{1}{2}$ years of postnatal life. Serum testosterone also remained at basal levels (i.e. nondetectable at $<0.02 \mathrm{ng} / \mathrm{mL}$ ) during the first $3 \frac{1}{2} 2$ years of postnatal life in male baboon offspring untreated or treated prenatally with letrozole or letrozole plus estradiol.

Glucose and insulin metabolic parameters in offspring Basal blood glucose and plasma insulin levels at the time of delivery near term were not significantly different in newborns delivered to baboons untreated $(74 \pm 6 \mathrm{mg} / \mathrm{dL}$ and $3.7 \pm 0.3 \mu \mathrm{IU} / \mathrm{mL}$, respectively) or treated in utero with letrozole or letrozole plus estradiol (Table 1). Basal levels of glucose immediately before the glucose (dextrose) tolerance test administered postnatally were also not significantly different in offspring from baboons untreated $(67 \pm 3 \mathrm{mg} / \mathrm{dL})$ or treated throughout the second half of gestation with letrozole $(69 \pm 2 \mathrm{mg} / \mathrm{dL})$ or with letrozole plus estradiol $(69 \pm 2 \mathrm{mg} / \mathrm{dL})$. However, basal insulin levels were over two-fold greater $(P=0.06)$ in offspring treated prenatally with letrozole $(12.3 \pm 3.6 \mu \mathrm{IU} / \mathrm{mL})$ than in untreated animals $(5.2 \pm 1.0 \mu \mathrm{IU} / \mathrm{mL})$ and restored after letrozole plus estradiol treatment $(6.9 \pm 1.9 \mu \mathrm{IU} / \mathrm{mL})$.

The patterns of glucose and insulin levels during the glucose challenge test in offspring delivered to untreated, letrozole-treated, and letrozole plus estradioltreated baboons are shown in Fig. 2. Within $1 \mathrm{~min}$ of a bolus i.v. injection of dextrose, blood glucose and plasma insulin increased to peak levels, then rapidly declined and were restored within $60-90 \mathrm{~min}$ to prechallenge levels. However, in baboon offspring treated in utero with letrozole, the peak $1 \mathrm{~min}$ postchallenge levels of glucose $(210 \pm 3 \mathrm{mg} / \mathrm{dL}$, Fig. 3A) and insulin $(113.8 \pm 18.7 \mu \mathrm{IU} / \mathrm{mL}$, Fig. 4A) were greater $(P<0.05$ and $P<0.01$, respectively) than in untreated animals $(188 \pm 6 \mathrm{mg} / \mathrm{dL}$ and $47.4 \pm 7.4 \mu \mathrm{IU} / \mathrm{mL}$, respectively), and completely (glucose) or partially (insulin) returned to normal in baboons treated in utero with letrozole plus estradiol $(192 \pm 3 \mathrm{mg} / \mathrm{dL}$ and $78.9 \pm 9.7 \mu \mathrm{IU} / \mathrm{mL}$, respectively). Moreover, the net elevations (i.e. 1 min peak minus baseline) in glucose (Fig. 3B) and insulin (Fig. 4B) levels also were greater ( $P=0.08$ and $P<0.01$, respectively) in letrozole-treated $(141 \pm 4 \mathrm{mg} / \mathrm{dL}$ and $101.4 \pm 16.8 \mu \mathrm{IU} / \mathrm{mL})$ than in untreated $(122 \pm 6 \mathrm{mg} / \mathrm{dL}$ and $42.3 \pm 7.6 \mu \mathrm{IU} / \mathrm{mg} / \mathrm{dL})$ offspring and completely (glucose) or partially (insulin) restored in letrozole plus estradiol-treated animals $(123 \pm 5 \mathrm{mg} / \mathrm{dL}$ and $71.9 \pm 11.4 \mu \mathrm{IU} / \mathrm{mL}$ ).

When the 1, 3, and 5 min levels in glucose and insulin were averaged, the overall mean levels of glucose $(183 \pm 4 \mathrm{mg} / \mathrm{dL})$ and insulin $(77.7 \pm 13.6 \mu \mathrm{IU} / \mathrm{mL})$ were

Table 2 Body weight, blood pressure, and serum chemistry analytes in baboon offspring.

\begin{tabular}{|c|c|c|c|c|c|c|}
\hline Treatment & Body weight (kg) & MABP $(\mathrm{mmHg})$ & AST (U/L) & Creatinine $(\mathrm{mg} / \mathrm{dL})$ & Triglycerides (mg/dL) & Cholesterol (mg/dL) \\
\hline Untreated & $9.6 \pm 0.1$ & $63 \pm 9$ & $34.4 \pm 7.6$ & $1.4 \pm 0.2$ & $52.1 \pm 5.0$ & $108 \pm 10.1$ \\
\hline Letrozole & $9.9 \pm 0.2$ & $60 \pm 10$ & $37.8 \pm 5.1$ & $1.3 \pm 0.1$ & $53.5 \pm 6.8$ & $112 \pm 9.2$ \\
\hline Letrozole + estradiol & $9.6 \pm 0.1$ & $62 \pm 8$ & $32.7 \pm 4.2$ & $1.5 \pm 0.3$ & $51.7 \pm 4.9$ & $109 \pm 7.2$ \\
\hline
\end{tabular}

Values are expressed as mean \pm S.E.M. at 3 years of age in offspring delivered to baboons untreated $(n=10)$ or treated on days $100-165 / 175$ of gestation with letrozole $(n=5)$ or letrozole + estradiol $(n=4)$.

http://joe.endocrinology-journals.org DOI: 10.1530/JOE-15-0530
C 2016 Society for Endocrinology Printed in Great Britain
Published by Bioscientifica Ltd. 
A
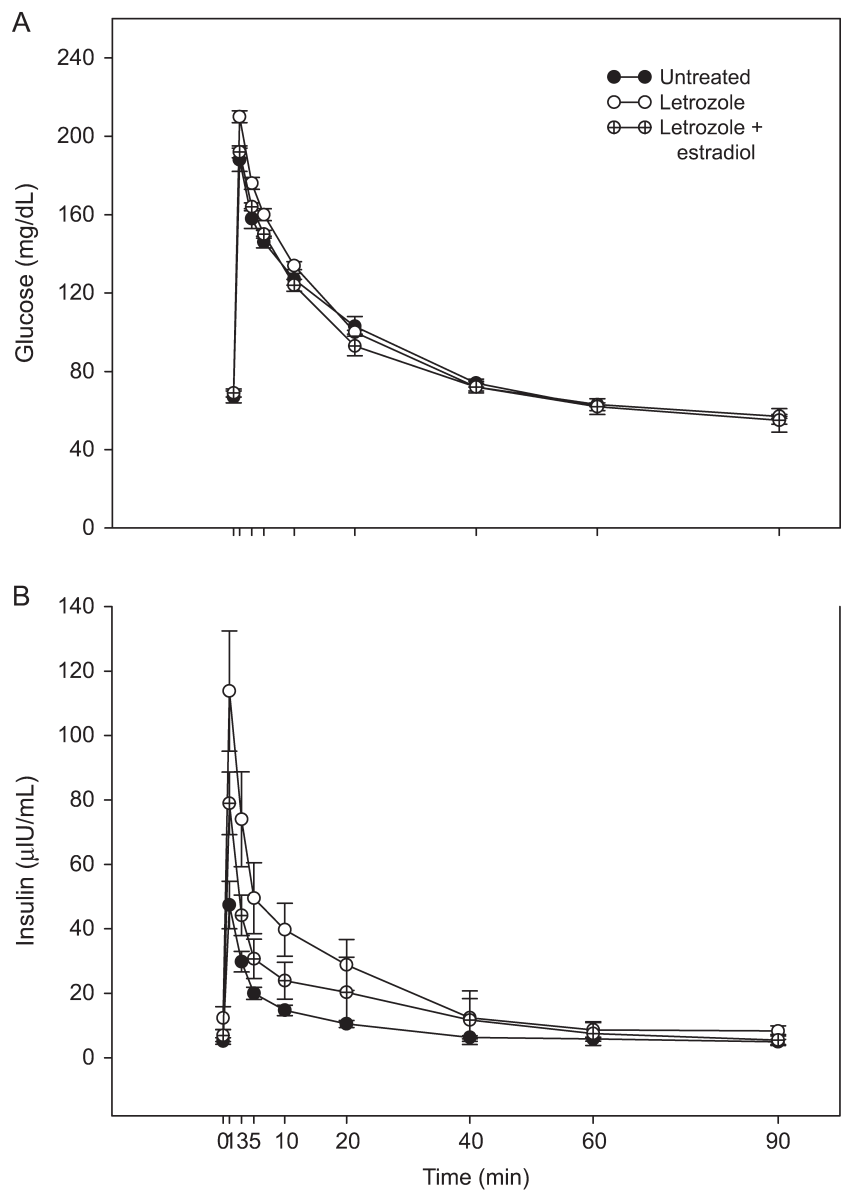

Figure 2

Patterns of blood glucose (A) and plasma insulin (B) levels after i.v. administration at time 0 min of a bolus of dextrose during postnatal life to prepubertal offspring delivered to baboons untreated $(n=10)$ or treated with letrozole $(n=5)$ or letrozole + estradiol $(n=4)$ as detailed in the legend of Fig. 1. Values at each time point are the mean \pm S.E.M. of the average of several glucose challenge tests performed longitudinally (i.e. every $6-12$ months) in each animal at $1-3 \frac{1}{4}$ years of postnatal life (i.e. before puberty).

greater $(P<0.05$ and $P<0.01$, respectively) in baboon offspring treated prenatally with letrozole than that in animals untreated and partially restored by letrozole plus estradiol administration (Table 3). The overall mean levels of blood glucose $(114 \pm 5 \mathrm{mg} / \mathrm{dL})$ and plasma insulin $(65.4 \pm 11.7 \mu \mathrm{IU} / \mathrm{mL})$ at 1,3 , and $5 \mathrm{~min}$ minus baseline level also were greater ( $P=0.07$ and $P<0.01$, respectively) in baboons treated in utero with letrozole than that in untreated animals and restored by treatment with letrozole plus estradiol (Table 3). The values of area under the curve (AUC) for glucose $(1,098 \pm 21)$ and insulin $(574 \pm 85)$ in offspring from letrozole-treated baboons were also greater $(P<0.05$ and $P<0.001$, respectively) than that in untreated animals and partially restored in letrozole plus

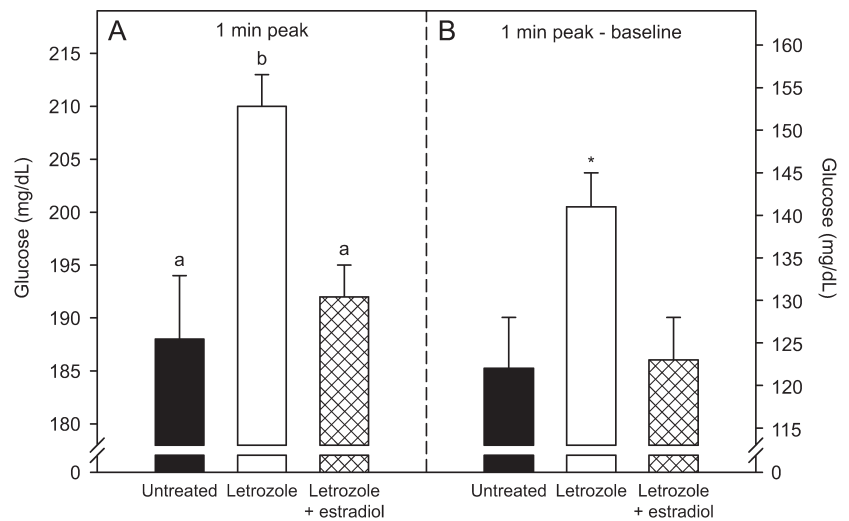

Figure 3

Blood glucose levels, expressed as $1 \mathrm{~min}$ peak (panel A) and $1 \mathrm{~min}$ peak-baseline (panel B) levels, after administration of an i.v. bolus of dextrose to baboon offspring untreated $(n=10)$ or treated in utero with letrozole $(n=5)$ or letrozole + estradiol $(n=4)$. Values of the bars in panel $A$ with different letters are significantly different from each other $\left(P<0.05\right.$, ANOVA, Tukey-Kramer multiple comparison test). ${ }^{*} P=0.08$ versus untreated or letrozole + estradiol groups (panel B, ANOVA, Kruskal-Wallis nonparametric test).

estradiol-treated animals (Table 3). The ratio of glucose AUC to insulin AUC was lower $(P<0.01)$ in offspring delivered to letrozole-treated baboons $(2.04 \pm 0.25)$ than that in untreated offspring, indicative of increased capacity for insulin secretion, and restored to normal with letrozole plus estradiol treatment (Table 3).

The HOMA-IR and QUICKI have not been validated for use in prepubertal and pregnant baboons. However, they are well established as indices of insulin resistance and insulin sensitivity in the human and many animal

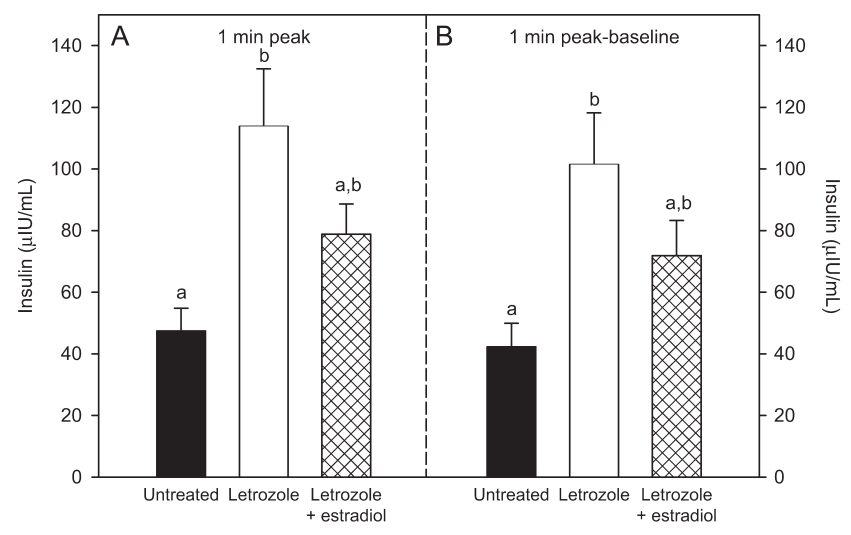

Figure 4

Plasma insulin levels, expressed as $1 \mathrm{~min}$ peak (panel A) and $1 \mathrm{~min}$ peak-baseline (panel B) levels, after administration of an i.v. bolus of dextrose to the same baboon offspring in which serum glucose levels are shown in Fig. 3. Values of the bars with different letters are significantly different from each other $(P<0.01$, ANOVA, Tukey-Kramer multiple comparison test).

Published by Bioscientifica Ltd. 
Table 3 Blood glucose and plasma insulin levels in baboon offspring after an i.v. glucose tolerance test.

\begin{tabular}{|c|c|c|c|c|c|c|c|}
\hline \multirow[b]{2}{*}{ Treatment } & \multicolumn{2}{|c|}{ Glucose (mg/dL) } & \multirow[b]{2}{*}{$\begin{array}{l}\text { Glucose } \\
\text { (AUC) }\end{array}$} & \multicolumn{2}{|c|}{ Insulin $(\mu \mathrm{IU} / \mathrm{mL})$} & \multirow[b]{2}{*}{$\begin{array}{l}\text { Insulin } \\
\text { (AUC) }\end{array}$} & \multirow{2}{*}{$\begin{array}{c}\text { Glucose AUC: } \\
\text { Insulin AUC } \\
\text { ratio }\end{array}$} \\
\hline & Mean $1+3+5 \min$ & $\begin{array}{c}\text { Mean } 1+3+5 \min - \\
\text { baseline }\end{array}$ & & Mean $1+3+5 \min$ & $\begin{array}{c}\text { Mean } 1+3+5 \min - \\
\text { baseline }\end{array}$ & & \\
\hline Untreated & $165 \pm 4^{a}$ & $99 \pm 5$ & $977 \pm 34^{a}$ & $32.4 \pm 3.8^{\mathrm{a}}$ & $26.6 \pm 4.4^{a}$ & $192 \pm 23^{a}$ & $5.84 \pm 0.72^{a}$ \\
\hline Letrozole & $183 \pm 4^{b}$ & $114 \pm 5^{*}$ & $1098 \pm 21 b$ & $77.7 \pm 13.6^{b}$ & $65.4 \pm 11.7 b$ & $574 \pm 85^{b}$ & $2.04 \pm 0.25^{b}$ \\
\hline $\begin{array}{l}\text { Letrozole+ } \\
\text { estradiol }\end{array}$ & $169 \pm 2^{a, b}$ & $99 \pm 5$ & $1006 \pm 10^{a, b}$ & $53.2 \pm 3.7 \mathrm{a}, \mathrm{b}$ & $44.9 \pm 2.2^{a, b}$ & $318 \pm 22^{c}$ & $3.24 \pm 0.27 a$ \\
\hline
\end{tabular}

Values are the mean \pm S.E.M. of the average levels of blood glucose and plasma insulin at 1, 3, and 5 min, area under curve (AUC) for glucose and insulin, and ratio of glucose AUC $\div$ insulin AUC after an i.v. bolus of dextrose to prepubertal offspring from baboons untreated $(n=10)$ or treated with letrozole $(n=5)$, or letrozole + estradiol $(n=4)$. Values with different letters are different from each other $(P<0.05$, glucose: $P<0.01$, insulin; ANOVA, TukeyKramer multiple comparison test). ${ }^{*} P=0.07$ vs untreated or letrozole + estradiol-treatment (ANOVA, Kruskal-Wallis test).

models and, therefore, were employed in the present study. The value for the HOMA-IR was over threefold greater $(P<0.05)$ in offspring delivered to baboons treated with the aromatase inhibitor letrozole $(2.20 \pm 0.70)$ than that in untreated animals $(0.65 \pm 0.09)$, and partially restored in animals treated with letrozole plus estradiol $(1.14 \pm 0.27$, Fig. $5 \mathrm{~A})$. The value for the QUICKI, an index highly correlated with assessment of insulin sensitivity using the euglycemic glucose clamp method (Katz et al. 2000, Chen et al. 2005, Lee et al. 2011), was lower $(P<0.01)$ in offspring from letrozole-treated baboons $(0.337 \pm 0.012)$ than that in untreated animals $(0.429 \pm 0.008)$ and restored to normal by letrozole plus estradiol administration $(0.388 \pm 0.025$, Fig. $5 \mathrm{~B})$.

There was no significant change, as analyzed by repeated measures mixed-model ANOVA, in the various glucose and insulin indices obtained sequentially during postnatal development in offspring delivered to



Figure 5

(A) HOMA-IR (i.e. basal glucose $\times$ basal insulin levels $\div 405$ ) and (B) QUICKI (i.e. $1 /(\log (\mathrm{IO})+\log (\mathrm{Go}))$, where lo is the basal insulin and Go the basal glucose levels) for the same baboon offspring in which serum glucose levels are shown in Fig. 3. Values of the bars with different letters are significantly different from each other $(P<0.05$ for HOMA-IR and $P<0.01$ for QUICKI, ANOVA, Tukey-Kramer multiple comparison test). untreated, letrozole-treated, or letrozole plus estradioltreated baboons. For example, mean \pm s.e.m. values for glucose AUC in untreated offspring were $929 \pm 75$, $1016 \pm 33$, and $1017 \pm 21$ at 1,2 , and 3 years of age, respectively. Mean \pm s.E.M. insulin AUC values also were similar in untreated offspring at $1(251 \pm 79), 2(203 \pm 37)$ and $3(219 \pm 35)$ years of age.

\section{Glucose and metabolic parameters in maternal} baboons Maternal body weight near term was similar in baboons untreated $(18.6 \pm 1.2 \mathrm{~kg})$ or treated with letrozole $(18.8 \pm 1.3 \mathrm{~kg})$ or letrozole plus estradiol $(18.6 \pm 1.0 \mathrm{~kg})$. The patterns of blood glucose and plasma insulin levels in maternal baboons during the glucose challenge test are shown in Fig. 6. Basal glucose (mg/dL) and insulin $(\mu \mathrm{IU} / \mathrm{mL})$ levels were similar in untreated ( $55 \pm 6$ and $22.5 \pm 6$, respectively), letrozole-treated ( $54 \pm 3$ and $10.7 \pm 5)$ and letrozole plus estradiol-treated $(52 \pm 5$ and $15.8 \pm 4$ ) baboons (Fig. 6 ). The mean ( \pm SE) of the $1+3+5$ min levels, AUC of glucose and insulin, and the ratio of glucose AUC/insulin AUC also was similar in each of the groups (Table 4). Moreover, HOMA-IR and QUICKI values (Fig. 7) were similar in untreated $(1.86 \pm 0.33,0.37 \pm 0.02)$, letrozole-treated $(1.70 \pm 0.97,0.38 \pm 0.02)$, and letrozole plus estradiol-treated $(2.24 \pm 0.70,0.35 \pm 0.02)$ baboon mothers.

Fetal insulin signaling components Skeletal muscle of fetuses delivered near term to untreated and letrozoletreated baboons expressed, via Western immunoblotting, the major protein components of the insulin signaling pathway, including IRS1 (approximate molecular size of $185 \mathrm{kDa}$ ), total Akt, Akt phosphorylated at threonine 308 or serine 473 (each $60 \mathrm{kDa}$ ), GLUT1, GLUT4, GLUT4 phosphorylated at serine 488 (each $55 \mathrm{kDa}$ ), and total AS160 $(160 \mathrm{kDa})$. Representative examples of these components of the insulin signaling pathway expressed

Published by Bioscientifica Ltd 

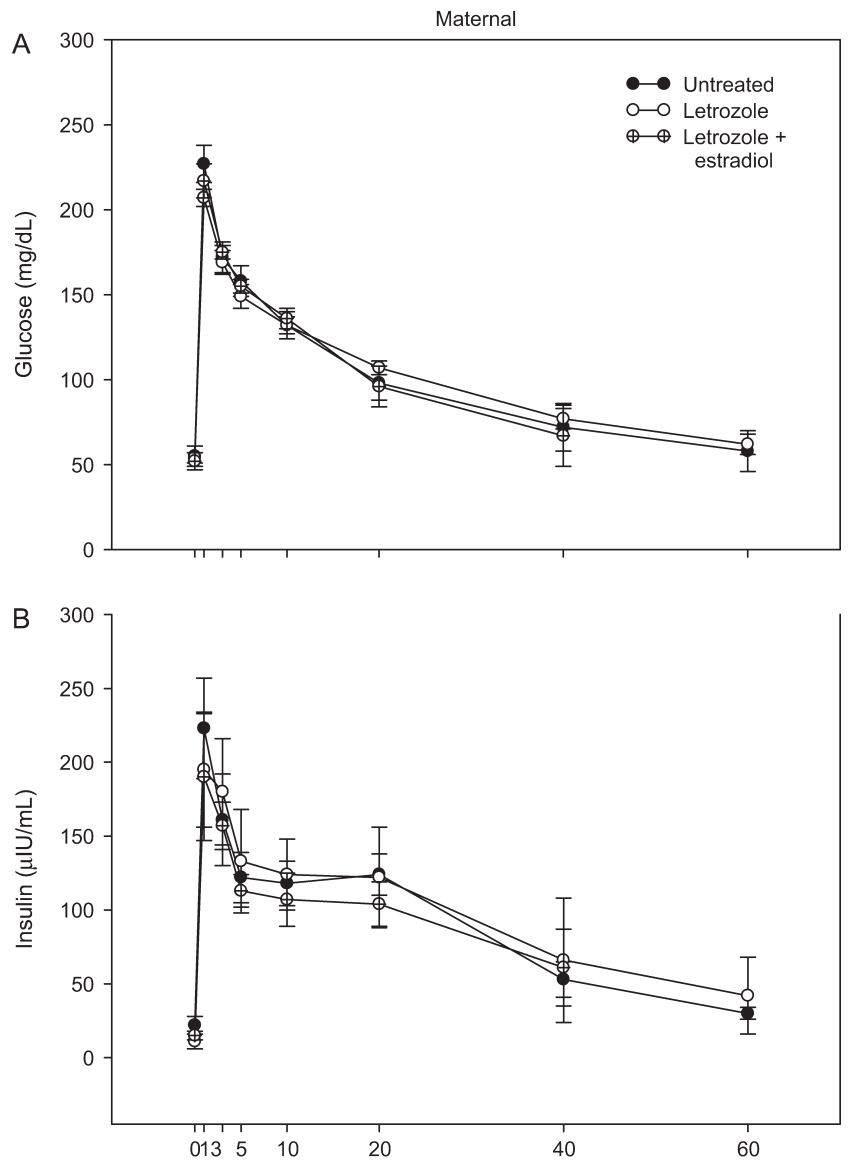

Figure 6

Mean \pm S.E.M. levels of blood glucose (A) and plasma insulin (B) after i.v. administration at time 0 min of a bolus of dextrose at 151-163 days of gestation in maternal baboons untreated $(n=4)$ or treated with letrozole $(n=6)$ or letrozole + estradiol $(n=4)$.

in fetal skeletal muscle of untreated and letrozole-treated baboons are shown in Fig. 8. Quantitative densitometric analyses showed that basal levels (i.e. noninsulin stimulated) of each of these proteins, expressed as a ratio to GAPDH, were similar in fetal skeletal muscle of baboons untreated or treated with letrozole (Table 5). Moreover, in the absence of insulin challenge, the mean ( \pm S.E.M.) ratios of p S ${ }^{473} \mathrm{Akt} / \mathrm{total}$ Akt $(0.144 \pm 0.031), \mathrm{p} \mathrm{T}^{308} \mathrm{Akt} /$ total Akt $(0.114 \pm 0.015)$, and p Glut-4/total Glut-4 $(2.50 \pm 0.43)$ in fetal skeletal muscle of letrozole-treated baboons were not different from values in untreated baboons $(0.112 \pm 0.020$; $0.113 \pm 0.030 ; 2.69 \pm 0.68$, respectively).

\section{Discussion}

The present study shows, for the first time in a nonhuman primate, that the peak rise in blood glucose level induced by a glucose challenge was greater in prepubertal offspring delivered to baboons in which estrogen had been suppressed throughout the second half of pregnancy than in animals exposed in utero to the normal elevation in estrogen. Moreover, the exaggerated rise in glucose levels of estrogen-suppressed baboon offspring was associated with significantly greater basal and glucose-induced levels of plasma insulin, as well as lower ratio of glucose AUC/ insulin AUC, indicating that the pancreatic beta cells had the capacity to secrete insulin, but that peripheral glucose uptake and/or metabolism were impaired, a condition indicative of insulin resistance or type 2 diabetes. We propose, therefore, that estrogen normally has an important role in programming mechanisms in utero within the developing fetus that lead to insulin sensitivity and the capacity to metabolize glucose after birth.

The latter concept is consistent with previous observations of impaired insulin sensitivity and glucose metabolism in aromatase-null laboratory mice (Jones et al. 2000, Takeda et al. 2003), in the few clinical cases of aromatase deficiency that have been reported in humans (Rochira et al. 2007, Zirilli et al. 2008, Belgorosky et al. 2009, Guercio et al. 2009), and in healthy men administered anastrozole to suppress aromatase (Gibb et al. 2016). In addition, ERo-null mice develop insulin resistance, glucose intolerance, and decreased glucose

Table 4 Blood glucose and plasma insulin levels in maternal baboons during an i.v. glucose tolerance test.

\begin{tabular}{|c|c|c|c|c|c|c|c|}
\hline \multirow[b]{2}{*}{ Treatment } & \multicolumn{2}{|c|}{ Glucose (mg/dL) } & \multirow[b]{2}{*}{$\begin{array}{l}\text { Glucose } \\
\text { (AUC) }\end{array}$} & \multicolumn{2}{|c|}{ Insulin $(\mu \mathrm{IU} / \mathrm{mL})$} & \multirow[b]{2}{*}{$\begin{array}{l}\text { Insulin } \\
\text { (AUC) }\end{array}$} & \multirow{2}{*}{$\begin{array}{c}\text { Glucose AUC: } \\
\text { Insulin AUC } \\
\text { ratio }\end{array}$} \\
\hline & Mean $1+3+5 \min$ & $\begin{array}{c}\text { Mean } \\
1+3+5 \text { min }- \text { basal }\end{array}$ & & Mean $1+3+5 \min$ & $\begin{array}{c}\text { Mean } \\
1+3+5 \text { min }- \text { basal }\end{array}$ & & \\
\hline Untreated & $185 \pm 9$ & $130 \pm 5$ & $869 \pm 44$ & $175 \pm 24$ & $153 \pm 30$ & $819 \pm 111$ & $1.16 \pm 0.27$ \\
\hline Letrozole & $179 \pm 5$ & $129 \pm 7$ & $844 \pm 28$ & $174 \pm 34$ & $166 \pm 31$ & $805 \pm 158$ & $1.19 \pm 0.29$ \\
\hline $\begin{array}{l}\text { Letrozole }+ \\
\text { estradiol }\end{array}$ & $182 \pm 5$ & $128 \pm 5$ & $858 \pm 14$ & $164 \pm 21$ & $145 \pm 20$ & $770 \pm 96$ & $1.18 \pm 0.15$ \\
\hline
\end{tabular}

Values are the mean \pm S.E.M. of the average levels of maternal blood glucose and plasma insulin at 1, 3, and 5 min, area under curve (AUC) for glucose and insulin, and glucose AUC $\div$ insulin AUC after an i.v. bolus of dextrose on days 151-163 of gestation to baboons untreated ( $n=4$ ) or treated with letrozole $(n=6)$, or letrozole + estradiol $(n=4)$.

http://joe.endocrinology-journals.org DOI: 10.1530/JOE-15-0530
C) 2016 Society for Endocrinology Printed in Great Britain
Published by Bioscientifica Ltd. 




Figure 7

HOMA-IR (A) and QUICKI (B) values for the baboon mothers, in which glucose and insulin levels are shown in Fig. 6 .

uptake in skeletal muscle (Couse \& Korach 1999, Heine et al. 2000, Bryzgalova et al. 2006, Ribas et al. 2011, Manrique et al. 2012). In contrast to estrogen deprivation, the administration of phytoestrogen to mice throughout gestation enhanced glucose tolerance in offspring at adulthood (Cederroth \& Nef 2009). Estrogen treatment reversed insulin resistance and normalized serum insulin levels in aromatase-deficient mouse offspring (Takeda et al. 2003). Moreover, low estrogen levels in adult laboratory rodents have been shown to result in insulin resistance in target tissues (Godsland 2005, Bryzgalova et al. 2008, Ropero et al. 2008, Nadal et al. 2009, Riant et al. 2009).

Our study takes on heightened translational clinical significance when considering exposure of the fetus during human pregnancy to endocrine disruptors which interfere with estrogen action (Diamanti-Kandarakis et al. 2009, Robins et al. 2011, Stel \& Legler 2015) and the increasingly high incidence of premature birth in humans (Voelker 2010), a condition that deprives the developing fetus of the normal elevation in estrogen of late gestation. However, preterm birth is also accompanied by lower than normal birth weight. Low birth weight resulting from preterm birth in humans (Barker 2005, Gluckman et al. 2008, Ross \& Beall 2008, Thompson \& Regnault 2011) and nonhuman primates (Blanco et al. 2010, 2015) and intrauterine growth restriction induced experimentally by placental insufficiency (Thorn et al. 2009), uterine artery ligation/uteroplacental insufficiency (Simmons et al. 2001), or maternal nutrient restriction (Ozanne et al. 1996, Desai et al. 1997, Kind et al. 2003, Choi et al. 2011) of laboratory animals result in insulin resistance in offspring. However, placental and fetal growth (Table 1), maternal glucose tolerance (Fig. 6 and Table 4), umbilical

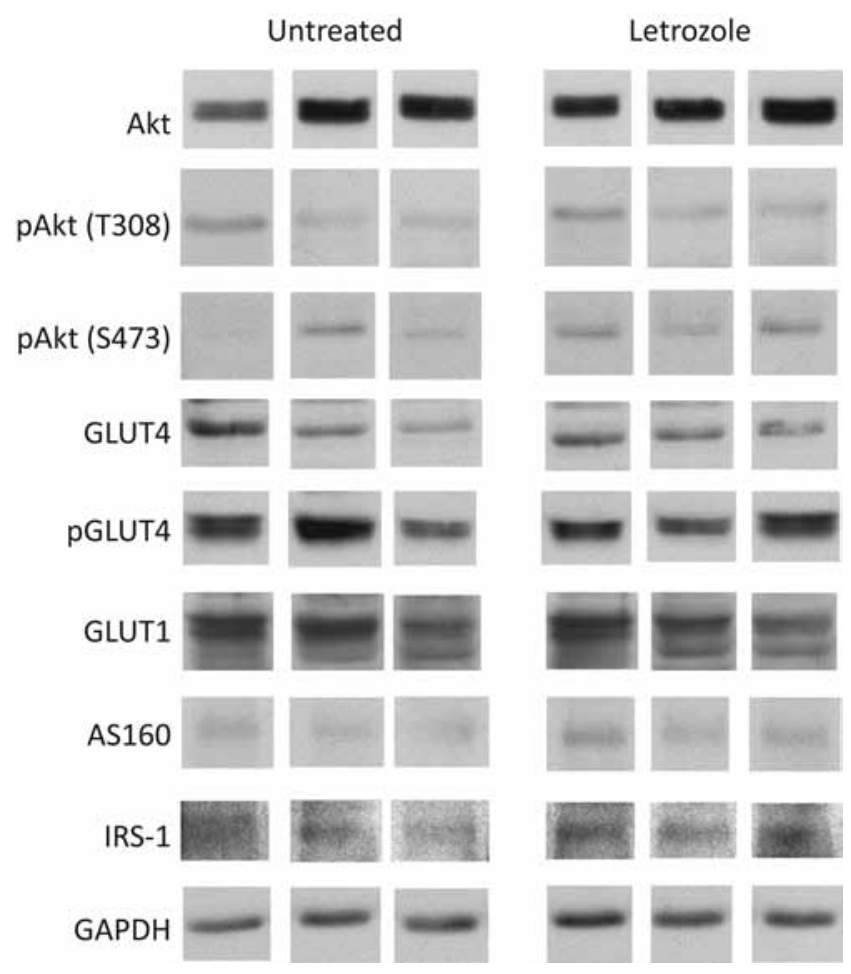

Figure 8

Representative Western immunoblot of total and phosphorylated insulin receptor signaling and GLUT proteins in extracts of skeletal muscle of fetuses obtained on day 165 of gestation from baboons untreated or treated with letrozole. Protein samples from untreated and letrozoletreated animals were applied side-by-side and electrophoresed on the same membrane. For illustrative purposes, each protein band was positioned separately below the untreated and letrozole columns as shown in this figure.

blood flow (Aberdeen et al. 2010), and placental villous vascularization (Robb et al. 2007) were not decreased in letrozole-treated/estrogen-deprived baboons. Overweight/ obesity also predicts insulin resistance in baboons (Chavez et al. 2008, 2009); however, body weight was normal in insulin-resistant offspring delivered to letrozole-treated baboons (Table 2). Therefore, the development of insulin resistance in offspring delivered to estrogen-deprived baboons of the current study was not associated with/ caused by a disruption of maternal glucose metabolism, utero-placental perfusion, fetal growth restriction, or overweight. We suggest that this points to the selective role of estrogen in programming processes during fetal development that promote insulin action after birth.

The mechanisms(s) by which estrogen programs processes in the developing primate fetus that prepare the offspring to respond to insulin after birth are unknown at this point. Insulin action requires a sequence of several essential steps, including development of an extensive

Published by Bioscientifica Ltd. 
Table 5 Skeletal muscle insulin signaling molecule protein levels in fetuses delivered to baboons untreated or treated with letrozole.

\begin{tabular}{|c|c|c|c|c|c|c|c|c|}
\hline & IRS-1 & Akt & pAkt(T) & pAkt(S) & GLUT4 & pGLUT4 & GLUT1 & AS160 \\
\hline Untreated & $0.39 \pm 0.15$ & $2.82 \pm 0.48$ & $0.30 \pm 0.06$ & $0.22 \pm 0.04$ & $0.60 \pm 0.16$ & $3.26 \pm 1.33$ & $3.58 \pm 1.19$ & $0.16 \pm 0.04$ \\
\hline Letrozole & $0.36 \pm 0.20$ & $3.40 \pm 1.06$ & $0.38 \pm 0.17$ & $0.27 \pm 0.06$ & $0.48 \pm 0.10$ & $2.73 \pm 0.86$ & $2.92 \pm 0.78$ & $0.25 \pm 0.09$ \\
\hline
\end{tabular}

Values are the mean \pm S.E.M. of skeletal muscle insulin signaling molecule protein levels (arbitrary densitometric units expressed as a ratio to GAPDH) quantified by Western immunoblot in fetuses obtained on day 165 of gestation from baboons untreated $(n=5)$ or treated daily on days $100-165$ with letrozole $(0.115 \mathrm{mg} / \mathrm{kg}$ body weight/day, sc, $n=5)$.

blood vessel network to deliver circulating insulin to cells of the target tissues (Richards et al. 2010); binding of insulin to the insulin receptor; phosphorylation of IRS; expression and phosphorylation/activation of the insulin receptor signaling molecules, e.g. serine/threonine kinase Akt, phosphatidylinositol, and glucose transporters notably GLUT4; and facilitated intracellular transport of glucose (Nystrom \& Quon 1999). Insulin receptor is expressed in high level in tissues of the human (Kaplan 1984) and baboon (Blanco et al. 2010) fetus. Insulin target tissues, such as skeletal muscle (Barros et al. 2006, Wiik et al. 2009) and adipose (Dieudonné et al. 2004), express estrogen receptor and thus are estrogen responsive. In rodents, estrogen upregulated the expression of GLUT4 (Barros et al. 2006, Moreno et al. 2010) and Akt (Vasconsuelo et al. 2008, Rogers et al. 2009) in skeletal muscle, and GLUT4 expression was impaired in insulinresistant rats (Kahn et al. 1991). In the current study, the basal total and phosphorylated levels of several components of the insulin signaling pathway, including IRS1, Akt, and GLUT4, were similar in skeletal muscle of near-term fetuses obtained from baboons untreated or treated with letrozole. However, whether the expression of these insulin signaling molecules in skeletal muscle and other insulin target tissues of fetuses or offspring delivered to estrogen-deprived baboons is altered after insulin challenge is unknown. Additional investigation is required, therefore, to determine the latter question and consequently the mechanisms that underlie the disruption of insulin sensitivity after birth induced by estrogen deprivation during fetal development.

In the present study, the glucose challenge-induced increases in blood glucose and plasma insulin in offspring delivered to baboons treated in utero with letrozole were largely but not completely prevented by concomitant administration of letrozole plus estradiol. This may have occurred because estradiol levels within the fetus of letrozole plus estradiol-treated baboons were only partially restored to normal since estradiol was administered to baboon mothers, and is not readily transferred across the placenta into the fetus due to placental metabolism and selective placental secretion of estrogen into the maternal compartment during human and nonhuman primate pregnancy (Albrecht \& Pepe 1990). However, testosterone levels were elevated in baboon fetuses treated with both the aromatase inhibitor letrozole and letrozole plus estradiol. Androgens, in high levels, have the capacity to impair insulin sensitivity (Golden et al. 2007), and administration of androgen to rhesus monkeys and sheep during early gestation disrupted insulin sensitivity in the offspring (Eisner et al. 2000, Bruns et al. 2004, Padmanabhan et al. 2010). Consequently, endogenous sex hormones may differentially regulate insulin sensitivity in men and women (Ding et al. 2006). An additional possibility, therefore, is that the insulin insensitivity and glucose intolerance, which developed in baboon offspring treated prenatally with letrozole, resulted from a combination of estrogen suppression and androgen excess, and thus an alteration in the ratio of estrogen and androgen.

In summary, the present study shows that the rise in serum glucose level induced by glucose challenge was greater in prepubertal offspring delivered to baboons deprived of estrogen during the second half of pregnancy than in animals exposed in utero to the normal elevation in estrogen. Since the exaggerated rise in glucose was accompanied by significantly greater levels of insulin, the results suggest a condition of insulin insensitivity and glucose intolerance. We propose, therefore, that estrogen normally has an important role in utero during primate pregnancy in programming mechanisms within the developing fetus that lead to insulin responsivity and the capacity to metabolize glucose in offspring after birth.

\section{Declaration of interest}

The authors declare that there is no conflict of interest that could be perceived as prejudicing the impartiality of the research reported.
(C) 2016 Society for Endocrinology Printed in Great Britain
Published by Bioscientifica Ltd. 
Funding

This work was supported by the National Institutes of Health R01 Research Grant DK93950.

\section{Acknowledgments}

The secretarial assistance of Mrs. Wanda James with computer word processing of the manuscript is greatly appreciated. The authors thank Novartis Pharma (Basel, Switzerland) for generously providing the aromatase inhibitor letrozole to conduct this study.

\section{References}

Aberdeen GW, Baschat AA, Harman CR, Weiner CP, Langenberg PW, Pepe GJ \& Albrecht ED 2010 Uterine and fetal blood flow indexes and fetal growth assessment after chronic estrogen suppression in the second half of baboon pregnancy. American Journal of Physiology: Heart and Circulatory Physiology 298 H881-H889.

Albrecht ED \& Pepe GJ 1990 Placental steroid hormone biosynthesis in primate pregnancy. Endocrine Reviews 11 124-150. (doi:10.1210/edrv11-1-124)

Albrecht ED, Aberdeen GW \& Pepe GJ 2000 The role of estrogen in the maintenance of primate pregnancy. American Journal of Obstetrics and Gynecology 182 432-438. (doi:10.1016/S0002-9378(00)70235-3)

Barker DJ 2005 The developmental origins of insulin resistance. Hormone Research 64 2-7. (doi:10.1159/000089311)

Barros RP, Machado UF \& Gustafsson JA 2006 Estrogen receptors: new players in diabetes mellitus. Trends in Molecular Medicine 12 425-431. (doi:10.1016/j.molmed.2006.07.004)

Barros RP, Gabbi C, Morani A, Warner M \& Gustafsson JA 2009 Participation of ERalpha and ERbeta in glucose homeostasis in skeletal muscle and white adipose tissue. American Journal of Physiology: Endocrinology and Metabolism 297 E124-E133.

Belgorosky A, Guercio G, Pepe C, Saraco N \& Rivarola MA 2009 Genetic and clinical spectrum of aromatase deficiency in infancy, childhood and adolescence. Hormone Research 72 321-330. (doi:10.1159/000249159)

Blanco CL, Liang H, Joya-Galeana J, DeFronzo RA, McCurnin D \& Musi N 2010 The ontogeny of insulin signaling in the preterm baboon model. Endocrinology 151 1990-1997. (doi:10.1210/en.2009-0777)

Blanco CL, McGill-Vargas LL, Gastaldelli A, Seidner SR, McCurnin DC, Leland MM, Anzueto DG, Johnson MC, Liang H, DeFronzo RA, et al. 2015 Peripheral insulin resistance and impaired insulin signaling contribute to abnormal glucose metabolism in preterm baboons. Endocrinology 156 813-823. (doi:10.1210/en.2014-1757)

Bruns CM, Baum ST, Colman RJ, Eisner JR, Kemnitz JW, Weindruch R \& Abbott DH 2004 Insulin resistance and impaired insulin secretion in prenatally androgenized male rhesus monkeys. Journal of Clinical Endocrinology \& Metabolism 89 6218-6223.

Bryzgalova G, Gao H, Ahren B, Zierath JR, Galuska D, Steiler TL, Dahlman-Wright K, Nilsson S, Gustafsson JA, Efendic S, et al. 2006 Evidence that oestrogen receptor-alpha plays an important role in the regulation of glucose homeostasis in mice; insulin sensitivity in the liver. Diabetologia 49 588-597. (doi:10.1007/s00125-005-0105-3)

Bryzgalova G, Lundholm L, Portwood N, Gustafsson JA, Khan A, Efendic S \& Dahlman-Wright K 2008 Mechanisms of antidiabetogenic and body weight-lowering effects of estrogen in high-fat diet-fed mice. American Journal of Physiology: Endocrinologoy and Metabolism 295 E904-E912.

Camporez JP, Jornayvaz FR, Lee HY, Kanda S, Guigni BA, Kahn M, Samuel VT, Carvalho CR, Petersen KF, Jurczak MJ, et al. 2013 Cellular mechanism by which estradiol protects female ovariectomized mice from high-fat diet-induced hepatic and muscle insulin resistance. Endocrinology 154 1021-1028. (doi:10.1210/en.2012-1989)

Cederroth CR \& Nef S 2009 Fetal programming of adult glucose homeostasis in mice. PLoS ONE $\mathbf{4}$ e7281.

Chavez AO, Lopez-Alvarenga JC, Tejero ME, Triplitt C, Bastarrachea RA, Sriwijitkamol A, Tantiwong P, Voruganti VS, Musi N, Comuzzle AG, et al. 2008 Physiological and molecular determinants of insulin action in the baboon. Diabetes $\mathbf{5 7} 899-908$. (doi:10.2337/db07-0790)

Chavez AO, Gastaldelli A, Guardado-Mendoza R, Lopez-Alvarenga JC, Leland MM, Tejero ME, Sorice G, Casiraghi F, Davalli A, Bastarrachea RA, et al. 2009 Predictive models of insulin resistance derived from simple morphometric and biochemical indices related to obesity and the metabolic syndrome in baboons. Cardiovascular Diabetology 8 22. (doi:10.1186/1475-2840-8-22)

Chen H, Sullivan G \& Quon MJ 2005 Assessing the predictive accuracy of QUICKI as a surrogate index for insulin sensitivity using a calibration model. Diabetes 54 1914-1925. (doi:10.2337/ diabetes.54.7.1914)

Choi SB, Jang JS \& Park S 2005 Estrogen and exercise may enhance beta-cell function and mass via insulin receptor substrate 2 induction in ovariectomized diabetic rats. Endocrinology 146 4786-4794. (doi:10.1210/en.2004-1653)

Choi J, Li C, McDonald TJ, Comuzzie A, Mattern V \& Nathanielsz PW 2011 Emergence of insulin resistance in juvenile baboon offspring of mothers exposed to moderate maternal nutrient reduction. American Journal of Physiology: Regulatory, Integrative and Comparative Physiology 301 R757-R762.

Couse JF \& Korach KS 1999 Estrogen receptor null mice: what have we learned and where will they lead us? Endocrine Reviews 20 358-417. (doi:10.1210/edrv.20.3.0370)

DeFronzo RA, Jacot E, Jequier E, Maeder Wahren J \& Felber JP 1981 The effect of insulin on the disposal of intravenous glucose. Results from indirect calorimetry and hepatic and femoral venous catheterization. Diabetes 30 1000-1007. (doi:10.2337/diab.30.12.1000)

Deroo BJ \& Korach KS 2006 Estrogen receptors and human disease. Journal of Clinical Investigation 116 561-570. (doi:10.1172/JCI27987)

Desai M, Byrne CD, Meeran K, Martenz ND, Bloom SR \& Hales CN 1997 Regulation of hepatic enzymes and insulin levels in offspring of rat dams fed a reduced-protein diet. American Journal of Physiology $\mathbf{2 7 3}$ G899-G904.

Diamanti-Kandarakis E, Bourguignon JP, Giudice LC, Hauser R, Prins GS, Soto AM, Zoeller RT \& Gore AC 2009 Endocrine-disrupting chemicals: an Endocrine Society scientific statement. Endocrine Reviews $\mathbf{3 0}$ 293-342. (doi:10.1210/er.2009-0002)

Dieudonné MN, Lenevue MC, Giudicelli Y \& Pecquery R 2004 Evidence for functional estrogen receptors alpha and beta in human adipose cells: regional specificities and regulation by estrogens. American Journal of Physiology: Cell Physiology 286 C655-C661.

Ding EL, Song Y, Malik VS \& Liu S 2006 Sex differences of endogenous sex hormones and risk of type 2 diabetes: a systematic review and meta-analysis. JAMA 295 1288-1299. (doi:10.1001/ jama.295.11.1288)

Eisner JR, Dumesic DA, Kemnitz JW \& Abbott DH 2000 Timing of prenatal androgen excess determines differential impairment in insulin secretion and action in adult female rhesus monkeys. Journal of Clinical Endocrinology \& Metabolism 85 1206-1210.

Gale EA \& Gillespie KM 2001 Diabetes and gender. Diabetologia 44 3-15. (doi:10.1007/s001250051573)

Gao H, Bryzgalova G, Hedman E, Khan A, Efendic S, Gustafsson JA \& Dahlman-Wright K 2006 Long-term administration of estradiol decreases expression of hepatic lipogenic genes and improves insulin sensitivity in ob/ob mice: a possible mechanism is through direct regulation of signal transducer and activator of transcription 3. Molecular Endocrinology 20 1287-1299. (doi:10.1210/me.2006-0012)

Published by Bioscientifica Ltd. 
Geer EB \& Shen W 2009 Gender differences in insulin resistance, body composition, and energy balance. Gender Medicine 6 60-75. (doi:10.1016/j.genm.2009.02.002)

Gibb FW, Homer NZ, Fagehi AM, Upreti R, Livingstone DE, McInnes KJ, Andrew R \& Walker BR 2016 Aromatase inhibition reduces insulin sensitivity in healthy men. Journal of Clinical Endocrinology and Metabolism 101 2040-2046. (doi:10.1210/jc.2015-4146)

Gluckman PD, Hanson MA, Cooper C \& Thornburg KL 2008 Effect of in utero and early-life conditions on adult health and disease. New England Journal of Medicine 359 61-73. (doi:10.1056/NEJMra0708473)

Godsland IF 2005 Oestrogens and insulin secretion. Diabetologia 48 2213-2220. (doi:10.1007/s00125-005-1930-0)

Golden SH, Dobs AS, Vaidya D, Szkio M, Gapstur S, Kopp P, Liu K \& Ouyang P 2007 Endogenous sex hormones and glucose tolerance status in postmenopausal women. Journal of Clinical Endocrinology \& Metabolism 92 1289-1295.

Gorres BK, Bomhoff GL, Morris JK \& Geiger PC 2011 In vivo stimulation of oestrogen receptor $\alpha$ increases insulin-stimulated skeletal muscle glucose uptake. Journal of Physiology 589 2041-2054. (doi:10.1113/ jphysiol.2010.199018)

Guercio G, Di Palma MI, Pepe C, Saraco NI, Prieto M, Saure C, Mazza C, Rivarola MA \& Belgorosky A 2009 Metformin, estrogen replacement therapy and gonadotropin inhibition fail to improve insulin sensitivity in a girl with aromatase deficiency. Hormone Research $\mathbf{7 2}$ 370-376. (doi:10.1159/000249165)

Gupte AA, Pownall HJ \& Hamilton DJ 2015 Estrogen: an emerging regulator of insulin action and mitochondrial function. Journal of Diabetes Research 2015 2015:916585.

Heine PA, Taylor JA, Iwamoto GA, Lubahn DB \& Cooke PS 2000 Increased adipose tissue in male and female estrogen receptor-alpha knockout mice. PNAS 97 12729-12734. (doi:10.1073/pnas.97.23.12729)

Heldring N, Pike A, Andersson S, Matthews J, Cheng G, Hartman J, Tujague M, Ström A, Treuter E, Warner M, et al. 2007 Estrogen receptors: how do they signal and what are their targets. Physiological Reviews 87 905-931. (doi:10.1152/physrev.00026.2006)

Jelenik T \& Roden M 2013 How estrogens prevent from lipid-induced insulin resistance. Endocrinology 154 989-992. (doi:10.1210/ en.2013-1112)

Jones ME, Thorburn AW, Britt KL, Hewitt KN, Wreford NG, Proietto J, Oz OK, Leury BJ, Robertson KM, Yao S, et al. 2000 Aromatase-deficient (ArKO) mice have a phenotype of increased adiposity. PNAS 97 12735-12740. (doi:10.1073/pnas.97.23.12735)

Kahn BB, Rossetti L, Lodish HF \& Charron MJ 1991 Decreased in vivo glucose uptake but normal expression of GLUT1 and GLUT4 in skeletal muscle of diabetic rats. Journal of Clinical Investigation $\mathbf{8 7}$ 2197-2206. (doi:10.1172/JCI115254)

Kaplan SA 1984 The insulin receptor. Journal of Pediatrics 104 327-336. (doi:10.1016/S0022-3476(84)81090-2)

Karjalainen A, Paassilta M, Heikkinen J, Bäckström AC, Savolainen M \& Kesäniemi YA 2001 Effects of peroral and transdermal oestrogen replacement therapy on glucose and insulin metabolism. Clinical Endocrinology 54 165-173. (doi:10.1046/j.1365-2265.2001.01208.x)

Katz A, Nambi SS, Mather K, Baron AD, Follmann DA, Sullivan G \& Quon MJ 2000 Quantitative insulin sensitivity check index: a simple, accurate method for assessing insulin sensitivity in humans. Journal of Clinical Endocrinology \& Metabolism 85 2402-2410.

Kind KL, Clifton PM, Grant PA, Owens PC, Sohlstrom A, Roberts CT, Robinson JS \& Owens JA 2003 Effect of maternal feed restriction during pregnancy on glucose tolerance in the adult guinea pig. American Journal of Physiology: Regulatory, Integrative and Comparative Physiology 284 R140-R152.

Lee HW, Muniyappa R, Yan X, Yue LQ, Linden EH, Chen H, Hansen BC \& Quon MJ 2011 Comparison between surrogate indexes of insulin sensitivity/resistance and hyperinsulinemic euglycemic glucose clamps in rhesus monkeys. Endocrinology 152 414-423. (doi:10.1210/ en.2010-1164)
Le May C, Chu K, Hu M, Ortega CS, Simpson ER, Korach KS, Tsai MJ \& Mauvais-Jarvis F 2006 Estrogens protect pancreatic beta-cells from apoptosis and prevent insulin-deficient diabetes mellitus in mice. PNAS 103 9232-9237. (doi:10.1073/pnas.0602956103)

Liu S \& Mauvais-Jarvis F 2010 Minireview: Estrogenic protection of beta-cell failure in metabolic diseases. Endocrinology 151 859-864. (doi:10.1210/en.2009-1107)

Louet JF, LeMay C \& Mauvais-Jarvis F 2004 Antidiabetic actions of estrogen: insight from human and genetic mouse models. Current Atherosclerosis Reports 6 180-185. (doi:10.1007/s11883-004-0030-9)

Lundholm L, Bryzgalova G, Gao H, Portwood N, Falt S, Berndt KD, Dicker A, Galuska D, Zierath JR, Gustafsson JA, et al. 2008 The estrogen receptor \{alpha\}-selective agonist propyl pyrazole triol improves glucose tolerance in ob/ob mice; potential molecular mechanisms. Journal of Endocrinology 199 275-286. (doi:10.1677/JOE-08-0192)

Manrique C, Lastra G, Habibi J, Mugerfeld I, Garro M \& Sowers JR 2012 Loss of estrogen receptor $\alpha$ signaling leads to insulin resistance and obesity in young and adult female mice. Cardiorenal Medicine $\mathbf{2}$ 200-210. (doi:10.1159/000339563)

Manson JE, Chlebowski RT, Stefanick ML, Aragaki AK, Rossouw JE, Prentice RL, Anderson G, Howard BV, Thomson CA, LaCroix AZ, et al 2013 Menopausal hormone therapy and health outcomes during the intervention and extended poststopping phases of the Women's Health Initiative randomized trials. JAMA 310 1353-1358. (doi:10.1001/jama.2013.278040)

Margolis KL, Bonds DE, Rodabough RJ, Tinker L, Phillips LS, Allen C, Bassford T, Burke G, Torrens J \& Howard BV 2004 Effect of oestrogen plus progestin on the incidence of diabetes in postmenopausal women: results from the Women's Health Initiative Hormone Trial. Diabetologia 47 1175-1187.

Mauvais-Jarvis F, Clegg DJ \& Hevener AL 2013 The role of estrogens in control of energy balance and glucose homeostasis. Endocrine Reviews 34 309-338. (doi:10.1210/er.2012-1055)

Moran A, Jacobs DR Jr, Steinberger J, Steffen LM, Pankow JS, Hong CP \& Sinaiko AR 2008 Changes in insulin resistance and cardiovascular risk during adolescence: establishment of differential risk in males and females. Circulation 117 2361-2368. (doi:10.1161/ CIRCULATIONAHA.107.704569)

Moreno M, Ordoñez P, Alonso A, Diaz F, Tolivia J \& Gonsález 2010 Chronic 17 beta-estradiol treatment improves skeletal muscle insulin signaling pathway components in insulin resistance associated with aging. Age 32 1-13. (doi:10.1007/s11357-009-9095-2)

Nadal A, Alonso-Magdalena P, Soriano S, Quesada I \& Ropero AB 2009 The pancreatic beta-cell as a target of estrogens and xenoestrogens: implications for blood glucose homeostasis and diabetes. Molecular and Cellular Endocrinology 304 63-68. (doi:10.1016/j. mce.2009.02.016)

Nystrom FH \& Quon MJ 1999 Insulin signalling: metabolic pathways and mechanisms for specificity. Cellular Signalling 11 563-574. (doi:10.1016/S0898-6568(99)00025-X)

Overkamp D, Gauthier JF, Renn W, Pickert A, Scheen AJ, Schmülling RM, Eggstein M \& Lefèbvre PJ 1997 Glucose turnover in humans in basal state and after intravenous glucose: a comparison of two models. American Journal of Physiology 273 E284-E296.

Ozanne SE, Smith GD, Tikerpae J \& Hales CN 1996 Altered regulation of hepatic glucose output in the male offspring of protein-malnourished rat dams. American Journal of Physiology 270 E559-E564.

Padmanabhan V, Veiga-Lopez A, Abbott DH, Recabarren SE \& Herkimer C 2010 Developmental programming: impact of prenatal testosterone excess and postnatal weight gain on insulin sensitivity index and transfer of traits to offspring of overweight females. Endocrinology 151 595-605. (doi:10.1210/en.2009-1015)

Paik SG, Michelis MA, Kim YT \& Shin S 1982 Induction of insulindependent diabetes by streptozotocin. Inhibition by estrogens and potentiation by androgens. Diabetes 31 724-729. (doi:10.2337) diab.31.8.724) 
Pepe GJ \& Albrecht ED 1995 Actions of placental and fetal adrenal steroid hormones in primate pregnancy. Endocrine Reviews 16 608-648.

Riant E, Waget A, Cogo H, Arnal JF, Burcelin R \& Gourdy P 2009 Estrogens protect against high-fat diet-induced insulin resistance and glucose intolerance in mice. Endocrinology $1502109-2117$. (doi:10.1210/en.2008-0971)

Ribas V, Drew BG, Le JA, Soleymani T, Daraei P, Sitz D, Mohammad L, Henstridge DC, Febbraio MA, Hewitt SC, et al. 2011 Myeloid-specific estrogen receptor alpha deficiency impairs metabolic homeostasis and accelerates atherosclerotic lesion development. PNAS 10816457 16462. (doi:10.1073/pnas.1104533108)

Richards OC, Raines SM \& Attie AD 2010 The role of blood vessels, endothelial cells, and vascular pericytes in insulin secretion and peripheral insulin action. Endocrine Reviews 31 343-363. (doi:10.1210/ er.2009-0035)

Robb VA, Pepe GJ \& Albrecht ED 2007 Placental villous vascular endothelial growth factor expression and vascularization after estrogen suppression during the last two-thirds of baboon pregnancy. Endocrine 31 260-267. (doi:10.1007/s12020-007-0036-5)

Robins JC, Marsit CJ, Padbury JF \& Sharma SS 2011 Endocrine disruptors, environmental oxygen, epigenetics and pregnancy. Frontiers in Bioscience 3 690-700. (doi:10.2741/e279)

Rochira V, Faustini-Fustini M, Balestrieri A \& Carani C 2000 Estrogen replacement therapy in a man with congenital aromatase deficiency: effects of different doses of transdermal estradiol on bone mineral density and hormonal parameters. Journal of Clinical Endocrinology \& Metabolism 85 1841-1845.

Rochira V, Madeo B, Zirilli L, Caffagni G, Maffei L \& Carani C 2007 Oestradiol replacement treatment and glucose homeostasis in two men with congenital aromatase deficiency: evidence for a role of oestradiol and sex steroids imbalance on insulin sensitivity in men. Diabetic Medicine 24 1491-1495. (doi:10.1111/j.1464-5491.2007.02304.x)

Rogers NH, Witczak CA, Hirshman MF, Goodyear LJ \& Greenberg AS 2009 Estradiol stimulates Akt, Amp-activated protein kinase (AMPK) and TBC1D1/4, but not glucose uptake in rat soleus. Biochemical and Biophysical Research Communications 382 646-650.

Ropero AB, Alonso-Magdalena P, Quesada I \& Nadal A 2008 The role of estrogen receptors in the control of energy and glucose homeostasis. Steroids 73 874-879. (doi:10.1016/j.steroids.2007.12.018)

Ross MG \& Beall MH 2008 Adult sequelae of intrauterine growth restriction. Seminars in Perinatology 32 213-218.
Simmons RA, Templeton LJ \& Gertz SJ 2001 Intrauterine growth retardation leads to the development of type 2 diabetes in the rat. Diabetes 50 2279-2286. (doi:10.2337/diabetes.50.10.2279)

Stel J \& Leglar J 2015 The role of epigenetics in the latent effects of early life exposure to obesogenic endocrine disrupting chemicals. Endocrinology 156 3466-3472. (doi:10.1210/en.2015-1434)

Takeda K, Toda K, Saibara T, Nakagawa M, Saika K, Onishi T, Sugiura T \& Shizuta Y 2003 Progressive development of insulin resistance phenotype in male mice with complete aromatase (CYP19) deficiency. Journal of Endocrinology 176 237-246. (doi:10.1677/ joe.0.1760237)

Thompson JA \& Regnault TR 2011 In utero origins of adult insulin resistance and vascular dysfunction. Seminars in Reproductive Medicine 29 211-224.

Thorn SR, Regnault TR, Brown LD, Rozance PJ, Keng J, Roper M, Wilkening RB, Hay WW Jr \& Friedman JE 2009 Intrauterine growth restriction increases fetal hepatic gluconeogenic capacity and reduces messenger ribonucleic acid translation initiation and nutrient sensing in fetal liver and skeletal muscle. Endocrinology $1503021-3030$. (doi:10.1210/en.2008-1789)

Vasconsuelo A, Milanesi L \& Boland R 2008 17Beta-estradiol abrogates apoptosis in murine skeletal muscle cells through estrogen receptors: role of the phosphatidylinositol 3-kinase/Akt pathway. Journal of Endocrinology 196 385-397. (doi:10.1677/JOE-07-0250)

Voelker R 2010 US preterm births: “D” is for dismal. JAMA 303 116-117. (doi:10.1001/jama.2009.1895)

Wagner JD, Thomas MJ, Williams JK, Zhang L, Greaves KA \& Cefalu WT 1998 Insulin sensitivity and cardiovascular risk factors in ovariectomized monkeys with estradiol alone or combined with nomegestrol acetate. Journal of Clinical Endocrinology \& Metabolism $\mathbf{8 3}$ 896-901.

Wiik A, Ekman M, Johansson O, Jansson E \& Esbjörnsson M 2009 Expression of both oestrogen receptor alpha and beta in human skeletal muscle tissue. Histochemistry and Cell Biology 131 181-189. (doi:10.1007/s00418-008-0512-x)

Zachos NC, Billiar RB, Albrecht ED \& Pepe GJ 2004 Regulation of oocyte microvilli development in the baboon fetal ovary by estrogen. Endocrinology 145 959-966. (doi:10.1210/en.2003-1078)

Zirilli L, Rochira V, Diazzi C, Caffagni G \& Carani C 2008 Human models of aromatase deficiency. Journal of Steroid Biochemistry and Molecular Biology 109 212-218. (doi:10.1016/j.jsbmb.2008.03.026)

Received in final form 18 May 2016

Accepted 20 May 2016

Accepted Preprint published online 20 May 2016
(C) 2016 Society for Endocrinology Printed in Great Britain 